\title{
Cranial Morphology and Adaptations in Eocene Adapidae. I. Sexual Dimorphism in Adapis magnus and Adapis parisiensis
}

\author{
PHILIP D. GINGERICH \\ Museum of Paleontology, The University of Michigan, Ann Arbor, Michigan \\ 48109
} KEY WORDS Sexual dimorphism, Eocene primates, Adapidae, Adapis,
Phyletic dwarfing

\begin{abstract}
Adapis is one of the best known lemuriform fossil primates. Quantitative analysis of all well-preserved crania of Adapis magnus $(\mathrm{n}=8)$ and Adapis parisiensis ( $\mathrm{n}=12$ ) together with maxillary and mandibular dentitions preserving canines corroborates Stehlin's hypothesis that Adapis was sexually dimorphic. Males are from $13 \%$ to $16 \%$ larger than females in cranial length, corresponding to a weight dimorphism estimated at $44 \%$ to $56 \%$, and have relatively broader skulls with more prominent sagittal and nuchal crests. Canine dimorphism ranges from $13 \%$ to $19 \%$, which is equal to or only slightly greater than that expected as a result of body size dimorphism (i.e., relative canine dimorphism is slight or nonexistent). By comparison with living primates, the observed body size dimorphism in Adapis implies a polygynous breeding system. Cebus apella is a diurnal arboreal living primate with moderate body size dimorphism and slight relative canine dimorphism and one can speculate that Adapis lived in polygynous multimale troops of moderate size like those of C. appella. Adapis extends the geological history of sexual dimorphism and polygyny in primates back to the Eocene. Extant lemuriform primates are generally not dimorphic or polygynous and they clearly do not adequately represent the range of social adaptations present in Eocene primates. The evolutionary lineage from Adapis magnus to Adapis parisiensis exhibits reduction in body size and in relative canine size, and phyletic dwarfing in Adapis is possibly an adaptive response to increasing climatic seasonality and environmental instability in the late Eocene and early Oligocene.
\end{abstract}

The fossil record of primate evolution is important for several reasons. First, it provides unequivocal evidence that primates have changed through time: genera familiar today are not found in Miocene, Oligocene, Eocene, or older intervals of geological time. Secondly, fossils provide a reasonably coherent outline of the phylogenetic history of primates. Finally, fossils provide the only direct evidence of the nature of adaptive mosaics or grades achieved by primates at different stages in their history. In this paper and the following one (Gingerich and Martin, 1981), we attempt to reconstruct aspects of the paleobiology of late Eocene lemuriform primates of the genus Adapis. When similar analyses of other well-known fossil pri- mates are available, it will be easier to characterize major trends in primate evolution in terms of the functional pathways and adaptive grades these represent.

Two major, diverse families of primates of modern aspect dominate Eocene and earliest Oligocene primate faunas on the northern continents. Tarsiiform Omomyidae were predominantly small (ca. 10-600 gm weight), insectivorous or frugivorous, nocturnal leaping arboreal forms (Szalay, 1976; Fleagle, 1978; Gingerich, 1981b). Lemuriform Adapidae were generally larger (ca. 100-8,000 gm weight), frugivorous or folivorous, diurnal leaping arboreal

Received March 11, 1981; accepted June 22, 1981. 
primates (Stehlin, 1912; Gregory, 1920; Gingerich, 1980). European adapids are placed in the subfamily Adapinae (Fig. 1) and most North American adapids are placed in a separate subfamily Notharctinae, reflecting the divergent evolutionary histories of Adapidae in these two biogeographical regions. Adapis, the genus analyzed here, is the type-genus of the family and one of the best known European adapids. As such, its functional morphology is of special importance for understanding the paleobiology of Adapidae; however, considering the broad diversity of this radiation, it should be stressed that Adapis is unlikely to be representative of the entire range of adaptations in Adapidae.

A number of authors have postulated that various genera of Eocene Adapidae were sexually dimorphic. Stehlin (1912: pp. 1231, 1258) recognized male and female specimens of Adapis parisiensis and A. magnus, based on relative canine size. Similarly, Gregory (1920: p. 125) identified the sex of several individual specimens of Notharctus based on canine size. Depéret (1917) made a passing reference to canine dimorphism in Adapis magnus, and Schmidt-Kittler (1971) referred female upper and lower canines to this species (Schmidt-Kittler's material has subsequently been transferred to Adapis stintoni Gingerich, 1977, see Fig. 1). I previously suggested that several specimens of primitive Smilodectes and Noth arctus could be sexed based on relative canine size (Gingerich, 1979a), but no adequate quantitative study of dimorphism in notharctines has yet been undertaken to substantiate this.

When studying sexual dimorphism in fossil assemblages it is important to establish that a

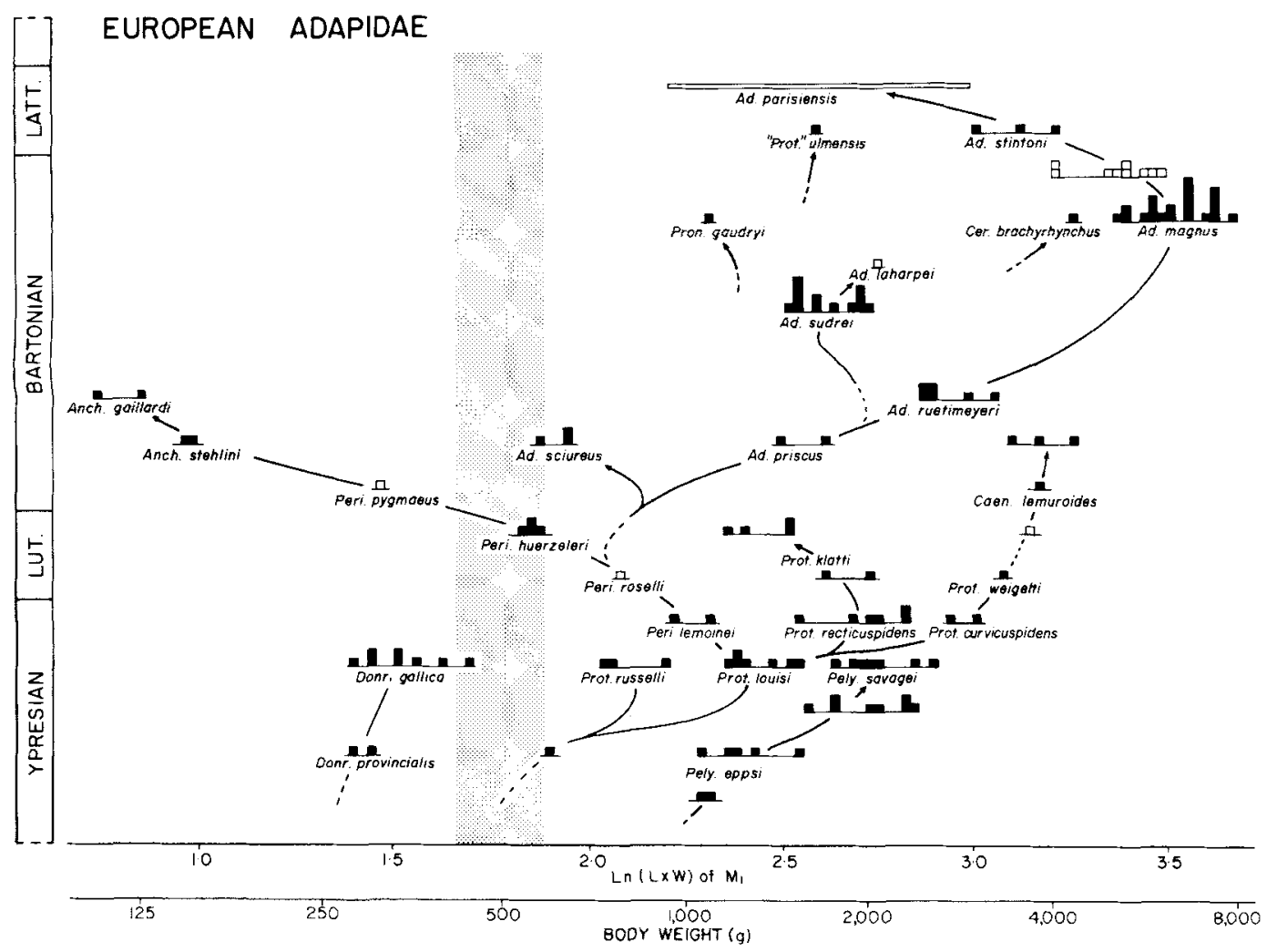

Fig. 1. Evolutionary radiation and relationships of the 28 known species of European Adapidae. Abscissa is tooth size and, by inference, body size: ordinate is time from about $53 \mathrm{Ma}$ to $37 \mathrm{Ma}$, spanning the Eocene and possibly earliest Oligocene (some authors include the Lattorfian/Priabonian in the early Oligocene). Stippling shows Kay's 500-gm threshold between insectivorous-frugivorous and frugivor- ous-folivorous primates (Kay, 1975; Kay and Hylander, 1978). Note position of Adapis on the frugivorous-folivorous side of this threshold, and rapid decrease in body size from A. magnus to $A$. stintoni and $A$. parisiensis. Adapis became extinct in Europe at the end of the Lattorfian (Grande Coupure). Modified from Gingerich $(1977,1980)$ using new body sizeltooth size regression from Gingerich et al. (1981). 
single species or lineage is being studied (Gingerich, 1981c). Large and small species of the same genus or closely related genera often occur together in fossil deposits and are easily confused. Multiple closely related species of the same geological age can best be recognized by the pattern of distribution of cheek tooth size, particularly the size of a central cheek tooth like $\mathrm{M}^{1}$ or $\mathrm{M}_{1}$ (Gingerich, 1974; Gingerich and Schoeninger, 1979). The size of cheek teeth may differ significantly (in a statistical sense) between males and females within dimorphic species, but this difference is never sufficient to be recognizably bimodal (Pilbeam and Zwell, 1972).

The two characteristics preserved in fossils that are most important for documenting sexual dimorphism within species are canine size and cranial or postcranial size (as a measure of overall body size dimorphism), and these are often distinctly bimodal. The degree of bimodality is a reflection of the amount of sexual dimorphism. Weakly dimorphic species may not show clear separation between males and females in canine size or cranial size even though mean values for each sex differ significantly and the dimorphism is regarded as biologically significant.

Adapis is one of the best known Eocene primates in terms of its dental and cranial anato$\mathrm{my}$, and the purpose of this study is to evaluate Stehlin's hypothesis that Adapis was sexual dimorphic. Evidence presented here is sufficient to characterize the nature of sexual dimorphism in Adapis, but interpretation of its possible sociobiological and phylogenetic significance is necessarily more speculative.

\section{MATERIALS AND METHODS}

The analysis of cranial dimorphism that follows is based on a total of 20 skulls, eight of $A d$ apis magnus and 12 of $A$. parisiensis, housed in European and American museums (Table 1). The analysis of canine dimorphism is based on a total of 33 specimens of $A$. magnus and 41 specimens of $A$. parisiensis preserving the crowns of maxillary or mandibular canines in the same jaw with upper and lower first molars. These specimens are housed in many different museums in Europe and North America (see Acknowledgments).

Adapis magnus is a late Bartonian species known from the European faunal reference intervals of Euzet and Perrière, whereas $A$. parisiensis is a late Lattorfian species known from the European faunal reference interval of Montmartre. The two species are never found together in the same deposits, although deposits of intermediate age (La Debruge reference interval, early Lattorfian) contain a species, $A$. stintoni, that is structurally intermediate between $A$. magnus and $A$. parisiensis (Ginger-

TABLE 1. Crania of Adapis magnus and Adapis parisiensis included in this study ${ }^{1}$

\begin{tabular}{|c|c|c|c|c|c|c|}
\hline Specimen no. & $\begin{array}{c}\text { Condylobasal } \\
\text { cranial } \\
\text { length (mm) }\end{array}$ & $\begin{array}{c}\text { Bizygomatic } \\
\text { cranial } \\
\text { width }(\mathrm{mm})\end{array}$ & $\begin{array}{l}\text { Canine } \\
\text { length }\end{array}$ & $\begin{array}{c}\text { Canine } \\
\text { width }\end{array}$ & $\begin{array}{l}\text { Canine } \\
\text { crown } \\
\text { height }\end{array}$ & Sex \\
\hline \multicolumn{7}{|c|}{ Adapis magnus } \\
\hline MNHN (Paris)-11035 & $115^{*}$ & $92^{*}$ & - & - & - & Male \\
\hline Montauban-1 & 111 & $82^{*}$ & 7.6 & 5.9 & $9.6^{*}$ & Male \\
\hline MNHN (Paris)-10870 & 110 & 85 & 7.0 & 5.5 & - & Male \\
\hline Montpellier-2 & - & - & 8.4 & 6.1 & 11.1 & Male \\
\hline MNHN (Paris)-10875 & $100^{*}$ & $76^{*}$ & 6.6 & 5.2 & 10.3 & Female \\
\hline Montauban-2 & $100^{*}$ & $65^{*}$ & - & - & - & Female \\
\hline Montpellier-1 & 95 & 70 & 6.3 & 5.2 & 8.9 & Female \\
\hline Princeton-11481 & $91 *$ & $62^{*}$ & - & - & - & Female \\
\hline \multicolumn{7}{|c|}{ Adapis parisiensis } \\
\hline Montauban-7 & 78 & $56^{*}$ & 4.7 & 2.9 & 4.4 & Male \\
\hline Cambridge M-538 & $76^{*}$ & 56 & - & - & - & Male \\
\hline Montauban-5 & 75 & 60 & - & - & - & Male \\
\hline BMNH (London) M-1345 & $75^{*}$ & 55 & 4.4 & 3.2 & 5.4 & Male \\
\hline Montauban -6 & 75 & 50 & 4.2 & 2.5 & 4.0 & Male \\
\hline Montpellier-5 & $73^{*}$ & - & 3.9 & 2.8 & 4.4 & Male \\
\hline Leuven P.LV-14 & 70 & - & 4.3 & 2.8 & 5.2 & Male \\
\hline Montpellier-4 & $67^{*}$ & $46^{*}$ & - & - & - & Female \\
\hline Montauban-4 & $67 *$ & $44^{*}$ & 4.1 & 2.7 & 4.3 & Female \\
\hline Bordeaux (P. betillei Type) & $66^{*}$ & $47^{*}$ & - & - & - & Female \\
\hline BMNH (London) M-1633 & 65 & $45^{*}$ & 3.5 & 2.2 & 3.4 & Female \\
\hline MNHN (Paris)-10873 & $64^{*}$ & $43^{*}$ & - & - & - & Female \\
\hline
\end{tabular}

Specimens listed in order of decreasing cranial length. Canine measurements are given where these teeth are present in skulls, Asterisks identify estimated measurements. For museum abbreviations see Acknowledgments. 
ich, 1977). Adapis magnus, A. stintoni, and $A$. parisiensis appear to represent successive stages of a single evolutionary lineage becoming smaller through time (Fig. 1). Coincidentally, the relative size of the upper and lower canine teeth in Adapis became reduced through time as well.

This evolutionary trend toward smaller overall size and relatively smaller canines seriously complicates the analysis presented here. Virtually all of the specimens discussed in this paper were originally found in the Phosphorites $d u$ Quercy, fissure fillings occupying late Eocene and Oligocene karst topography developed to the southwest of the Massif Central in France. The fossils, for the most part, were collected by miners during the last century and sold to dealers and museum representatives. Thus stratigraphic information and faunal associations are lacking for virtually all specimens (the sequence of Adapis species in Fig. 1 is based on faunally well-dated collections from other localities in Europe). Given the probability of significant change in body size and canine size through time, and the fact that individual specimens are not well dated, it is impossible to assume that samples of any species from early Quercy collections are contemporaneous. Thus existing museum collections could possibly contain both large specimens with large canines (primitive) and small specimens with small canines (advanced) of $A$. magnus or $A$. parisiensis simply because the collections represent a mixture of samples of different ages and not because the species themselves are dimorphic.

This quantitative study was initiated when it was discovered that skulls classified as Adapis magnus based on cheek tooth size appear to be of two distinct sizes. Similarly, skulls classified as $A$. parisiensis are either large or small, with few or no intermediates (Table 1, and Gingerich and Martin, 1981: Fig. 4). It is possible in view of their rarity that the bestpreserved skulls of $A$. magnus and $A$. parisiensis, respectively, were only preserved or discovered in one or a few Quercy deposits, each representing a limited time interval. In this case existing collections of crania may constitute reasonably homogeneous samples of each species. However, this postulate certainly does not apply to the abundant dental remains of $A$. parisiensis (Gingerich, 1977: Fig. 7) and it is unlikely to hold for dental remains of $A$. magnus either.

To compensate for the lack of temporal homogeneity in dental samples, it is necessary to use a measure of relative canine size standardized by reference to cheek tooth size, the one associated measure of body size that is not highly dimorphic. For this purpose I have calculated a canine/molar ratio (CMR) defined as:

$$
\mathrm{CMR}=\frac{\text { length } \times \text { width of upper canine }}{\text { length } \times \text { width of } \mathrm{M}^{1}}
$$

for upper teeth, or:

$$
\mathrm{CMR}=\frac{\text { length } \times \text { width of lower canine }}{\text { length } \times \text { width of } \mathrm{M}_{1}}
$$

for lower teeth.

Since the variability of this ratio is dependent in part on the absolute size of the specimens involved, an index of relative canine size (ICS) has been calculated as:

$$
\mathrm{ICS}=100 \times(\text { mean of } \mathrm{Ln} \mathrm{CMR})
$$

where a logarithmic transformation is used to standardize the variability of CMR. Similarly, an index of canine variability (ICV) has been calculated as:

$$
\mathrm{ICV}=100 \times \text { (standard deviation of } \mathrm{Ln} \mathrm{CMR}) .
$$

For both indices, CMR is calculated using Equation 1 or Equation 2, as appropriate.

These ratios and indices for Adapis are meaningless without comparative data for sexually nondimorphic and dimorphic living primates. For this purpose, representative samples of nondimorphic Hapalemur griseus, Avahi laniger, Propithecus verreauxi, Propithecus diadema, and Indri indri were measured at the British Museum (Natural History), London; the Rijksmuseum van Natuurlijke Historie, Leiden; the Muséum National d'Histoire Naturelle, Paris; and the Cleveland Museum of Natural History, Cleveland (Indriidae described in Gingerich and Ryan, 1979). Nondimorphic Aotus trivirgatus, and dimorphic Saimiri sciureus, Cebus apella, and Alouatta seniculus were measured at the Field Museum of Natural History, Chicago. Dr. Warren Kinzey supplied measurements of nondimorphic Callicebus moloch (Kinzey, 1972). Dr. Maurice Zingeser provided measurements of dimorphic Alouatta caraya (Zingeser, 1967), and measurements of dimorphic Pan troglodytes and Gorilla gorilla by Dr. David Pilbeam were taken from the literature (Pilbeam, 1969). These species provide an adequate, if not exhaustive, base for comparative interpretations of cranial and canine dimorphism in Adapis.

\section{CRANIAL DIMORPHISM IN ADAPIS}

It is possible to distinguish Quercy speci- 
mens of Adapis magnus from those of $A$. parisiensis based on the size of their cheek teeth. As Figure 1 shows, there is no overlap in the size of $\mathrm{M}_{1}$ in these two species; $A$. magnus is significantly larger than $A$. parisiensis. Intermediate forms from other European localities are classified as $A$. stintoni, but this species is very rare or absent in Quercy deposits.

Measurements of cranial length and breadth given in Table 1 show that among specimens classified as $A$. magnus on the basis of cheek tooth size, there are both large (average length $=112 \mathrm{~mm}$ ) and small (average length $=97 \mathrm{~mm}$ ) crania. Similarly, among specimens classified as $A$. parisiensis on the basis of the cheek tooth size, there are both large (average length $=75$ $\mathrm{mm}$ ) and small (average length $=66 \mathrm{~mm}$ ) crania (see also Gingerich and Martin, 1981: Fig. 4). The distribution of cranial length and width in $A$. magnus and $A$. parisiensis is shown in Figure 2, where allometric scaling in the two species of Adapis is compared with that in three species of nondimorphic Indriidae and three species of dimorphic Cebidae. In nondimorphis Avahi laniger, Propithecus verreauxi, and Indri indri, males and females overlap completely in cranial size. In contrast, in dimorphic Saimiri sciureus, Cebus apella, and Alouatta seniculus, males and females are well separated in cranial size (although there is still some overlap). Adapis magnus and A. parisien$s i s$, with sexes identified in Table 1 , exhibit a range of separation greatly exceeding that in the large samples of nondimorphic Indriidae, but approximating the male-female separation seen in dimorphic Cebidae.

It is worthy of note that the intraspecific width/length scaling coefficients (slopes) for species of both Indriidae and Cebidae range from 1.15 to 1.83 , whereas the interspecific scaling coefficients in these families are 0.67 and 0.82 , respectively. The intraspecific scaling coefficients for $A$. magnus and $A$. parisiensis are 1.83 and 1.63, compared with an interspecific coefficient of 1.20 . Technically the latter is a phylogenetic scaling coefficient not strictly comparable to the static interspecific coefficient of Indriidae and Cebidae, which may explain why it lies between values typical for true intraspecific and interspecific coefficients shown here. Nevertheless, the intraspecific coefficients in Adapis are higher than the interspecific coefficient, a pattern seen also in indriids and cebids, lending credibility to the grouping of Adapis specimens shown in Figure 2 and the existence of significant dimorphism in cranial size. If each of the four groups of Adapis skulls shown in Figure 2 represented a distinct evolutionary stage in the history of Adapis, what are here called intraspecific scaling coefficients would really be interspecific phyletic scaling coefficients. As a result, the "intraspecific" scaling coefficients should equal the interspecific coefficient, but this is not the case.

Male and female skulls of Adapis magnus are compared in Figure 3, and those of $A$. parisiensis are compared in Figure 4. In addition to being larger, the skulls of male Adapis tend to be relatively broader, with more flaring zygomatic arches. They also have stronger sagittal and nuchal crests.

Quantitatively, the ratio of average male cranial length to average female cranial length in A. magnus is $\mathbf{1 . 1 6}$ and this ratio in A. parisiensis is 1.13 (Table 2). To the extent that dimorphism in cranial length is representative of dimorphism in overall body size, these ratios suggest a body size dimorphism approximating that in Old and New World monkeys of moderate size (Leutenegger and Kelly, 1977; Alexander et al., 1979).

\section{CANINE DIMORPHISM IN ADAPIS}

In addition to dimorphism in cranial size, there is considerable variation in the size of the canine teeth in both Adapis magnus and Adapis parisiensis. Representative specimens of each species are illustrated in Figure 5 . Canine size dimorphism can be estimated by applying the ratio used by Leutenegger and Kelly (1977, but with male canine length/female canine length) to canine measurements of sexed specimens listed in Table 1. Canine size dimorphism using this method is 1.19 in $A$. magnus and 1.13 in $A$. parisiensis (Table 2); however, the samples in each case are small.

Many additional, less complete specimens of Adapis preserve canines, but these cannot be sexed independently. In addition, as explained in the section on Materials and Methods, analysis of the pattern of canine dimorphism is complicated by the fact that the geological age of most individual specimens is not known. Since these are sampled from an evolutionary lineage apparently undergoing reduction in both absolute body size and relative canine size, standardization is complicated. This can only be accomplished by calculating canine/ molar ratios (CMR) and indices of relative canine size (ICS) and relative canine variability (ICV) using Equations 1-4 above. Since many fossil specimens have the tips of the canines broken away, canine size is necessarily limited 

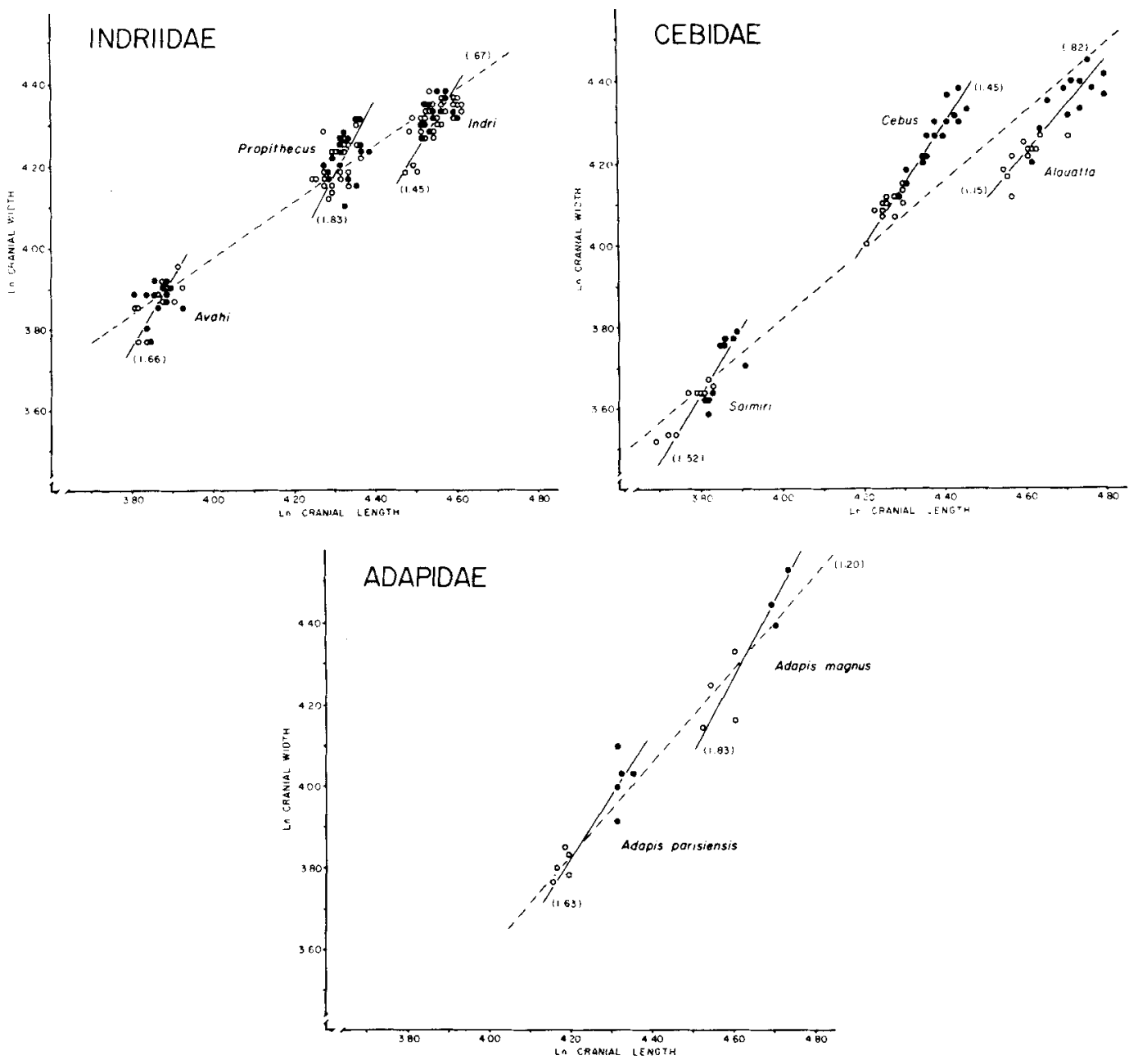

Fig. 2. Allometric scaling of cranial length and width in three species of nondimorphic Indriidae and three species of dimorphic Cebidae compared with scaling in two species of Adapis. Solid circles represent males; open circles are females. Note variability in cranial size and the separation of male and female crania in Cebidae but not in Indriidae. The distribution of cranial size in both species of Adapis most closely resembles that in dimorphic Cebidae. Solid line segments are principal axes for each distribution showing intraspecific scaling of cranial width/length. Scaling coef-

to a measure of the cross-sectional area of the upper or lower canine measured at the base of the crown.

Observed canine/molar ratios and indices of relative canine size and variability for Adapis magnus and $A$. parisiensis are summarized in Table 3, together with comparable statistics for representative dimorphic and nondimorphic species of living primates. It is not pos- ficients (slopes) are given in parentheses. Dashed lines are principal axes calculated for all specimens shown in each family (scaling coefficients in parentheses). Intraspecific scaling in Adapis exceeds interspecific scaling as in living models. If each cluster interpreted as male or female represents a different species, these "intraspecific" slopes should approximate the interspecific slope; they do not, substantiating the interpretation of moderate cranial dimorphism in Adapis shown here.

sible to sex most individual specimens of Adapis using absolute canine size, and the following argument is based on a comparison of patterns of distribution of canine size in Adapis with similar patterns in samples of dimorphic and nondimorphic living primates (again irrespective of the sex of individual specimens).

Values of mean CMR are listed in Table 3. 


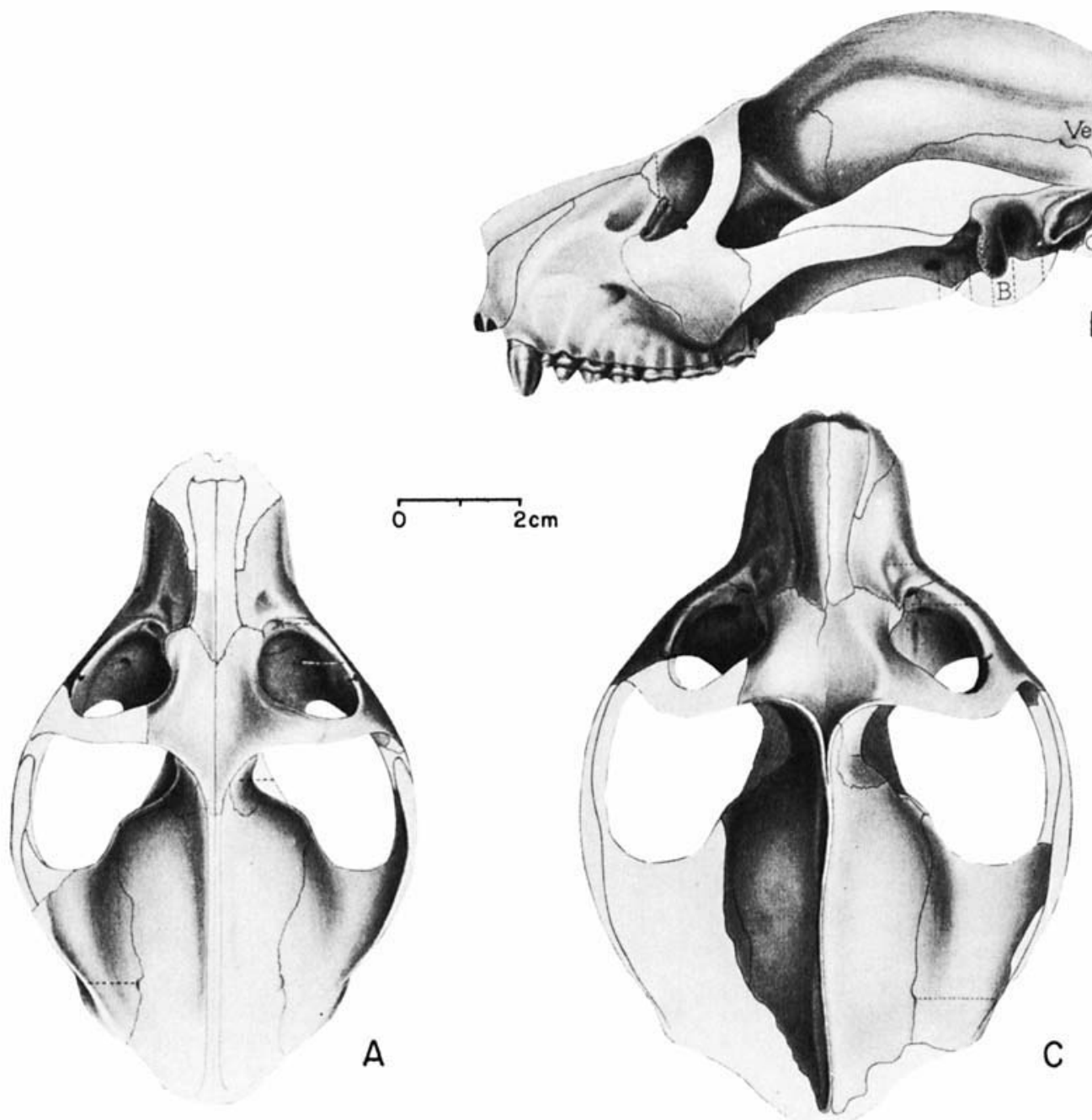

Fig. 3. Comparison of male and female crania of Adapis magnus. A, female (Montauban-2), in dorsal view. B and C, male (Montauban-1), in lateral and dorsal view. Figures from Stehlin (1912).

These are intuitively easier to understand than ICS, but use of mean CMR for comparison distorts differences between large and small species with differing amounts of absolute size variability. Conversion of all original ratios to logarithms using the index of relative canine size (ICS) corrects for this distortion and makes patterns of variation comparable in both large and small species. Correcting for differences in the variability of large and small species is most critical when variability itself is compared, and the ICS can be viewed as a necessary intermediate step to achieve comparable ICV values.
Comparison of mean CMR or ICS values for the living primates in Table 3 shows that, in general, nondimorphic primates have relatively small canines (mean CMR $=0.38-0.65$ in maxilla, $0.55-0.68$ in mandible), although there are exceptions (e.g., gibbons are nondimorphic but have large canines). Dimorphic primates tend to have relatively large canines (mean CMR $=0.74-1.51$ in maxilla, $0.86-1.45$ in mandible). Adapis magnus falls well within the range of living dimorphic primates in relative canine size, but Adapis parisiensis has smaller canines, indicating that there has been a reduction in relative canine size as well as body size 
TABLE 2. Statistical analysis of cranial size and canine size in sexed specimens of Adapis magnus and Adapis parisiensis, based on specimens listed in Table $1^{1}$

\begin{tabular}{|c|c|c|c|c|c|c|c|}
\hline Measurement & $\mathrm{N}$ & OR & $\bar{x}$ & $\mathrm{~S}$ & $\mathrm{~V}$ & $\mathrm{~V}_{\mathrm{n}}$ & $\mathrm{V}_{\mathrm{d}}$ \\
\hline \multicolumn{8}{|l|}{ Adapis magnus } \\
\hline \multicolumn{8}{|l|}{ Males } \\
\hline Cranial length* & 3 & $110.0-115.0$ & 112.00 & 2.65 & 2.4 & 3.6 & 4.7 \\
\hline Cranial width* & 3 & $82.0-92.0$ & 86.33 & 5.13 & 5.9 & 5.2 & 6.9 \\
\hline Canine length & 3 & $7.0-8.4$ & 7.67 & 0.70 & 9.2 & 5.5 & 6.3 \\
\hline Canine width & 3 & $5.5-6.1$ & 5.83 & 0.31 & 5.2 & 7.7 & 6.3 \\
\hline Canine height & 2 & $9.6-11.1$ & 10.35 & 1.06 & 10.2 & 8.8 & 6.6 \\
\hline \multicolumn{8}{|l|}{ Females } \\
\hline Cranial length & 4 & $91.0-100.0$ & 96.50 & 4.36 & 4.5 & 3.9 & 4.0 \\
\hline Cranial width & 4 & $62.0-76.0$ & 68.25 & 6.13 & 9.0 & 5.1 & 4.4 \\
\hline Canine length & 2 & $6.3-6.6$ & 6.45 & 0.21 & 3.3 & 5.8 & 5.4 \\
\hline Canine width & 2 & 5.2 & 5.20 & - & - & 6.7 & 7.0 \\
\hline Canine height & 2 & $8.9-10.3$ & 9.60 & 0.99 & 10.3 & 10.6 & 9.2 \\
\hline \multicolumn{8}{|l|}{ All } \\
\hline Cranial length & 7 & $91.5-115.0$ & 103.14 & 8.97 & 8.7 & 4.0 & 6.8 \\
\hline Cranial width & 7 & $62.0-92.0$ & 76.00 & 11.00 & 14.5 & 5.1 & 9.0 \\
\hline Canine length & 5 & $6.3-8.4$ & 7.18 & 0.83 & 11.7 & 6.0 & 12.5 \\
\hline Canine width & 5 & $5.2-6.1$ & 5.58 & 0.41 & 7.3 & 7.4 & 10.9 \\
\hline Canine height & 4 & $8.9-11.1$ & 9.98 & 0.94 & 9.5 & 9.4 & 25.7 \\
\hline
\end{tabular}

Cranial dimorphism: Male cranial length/female cranial length $=1.16$

Canine dimorphism: Male upper canine length/female upper canine length $=1.19$

Relative canine dimorphism: Canine dimorphism/cranial dimorphism $=1.03$

$\begin{array}{lrrrrrrr}\begin{array}{c}\text { Adapis parisiensis } \\ \text { Males }\end{array} & & & & & & & \\ \text { Cranial length* } & 7 & 70.0-78.0 & 74.57 & 2.51 & 3.4 & 3.6 & \\ \text { Cranial width* } & 5 & 50.0-60.0 & 55.40 & 3.58 & 6.5 & 5.2 & 6.9 \\ \text { Canine length } & 5 & 3.9-4.7 & 4.30 & 0.29 & 6.8 & 5.5 & 6.3 \\ \text { Canine width } & 5 & 2.5-3.2 & 2.84 & 0.25 & 8.8 & 7.7 & 6.3 \\ \text { Canine height } & 5 & 4.0-5.4 & 4.68 & 0.59 & 12.7 & 8.8 & 6.6 \\ \text { Females } & & & & & & & \\ \text { Cranial length } & 5 & 64.0-67.0 & 65.80 & 1.30 & 2.0 & 3.9 & 4.0 \\ \text { Cranial width } & 5 & 43.0-47.0 & 45.00 & 1.58 & 3.5 & 5.1 & 4.4 \\ \text { Canine length } & 2 & 3.5-4.1 & 3.80 & 0.42 & 11.2 & 5.8 & 5.4 \\ \text { Canine width } & 2 & 2.2-2.7 & 2.45 & 0.35 & 14.4 & 6.7 & 7.0 \\ \text { Canine height } & 2 & 3.4-4.3 & 3.85 & 0.64 & 16.5 & 10.6 & 9.2 \\ \text { All } & & & & & & & \\ \text { Cranial length } & 12 & 64.0-78.0 & 70.92 & 4.94 & 7.0 & 4.0 & 6.8 \\ \text { Cranial width } & 10 & 43.0-60.0 & 50.20 & 6.07 & 12.1 & 5.1 & 9.0 \\ \text { Canine length } & 7 & 3.5-4.7 & 4.16 & 0.38 & 9.2 & 6.0 & 12.5 \\ \text { Canine width } & 7 & 2.2-3.2 & 2.73 & 0.32 & 11.5 & 7.4 & 10.9 \\ \text { Canine height } & 7 & 3.4-5.4 & 4.44 & 0.68 & 15.4 & 9.4 & 25.7\end{array}$

Cranial dimorphism: Male cranial length/female cranial length $=1.13$

Canine dimorphism: Male upper canine length/female upper canine length $=1.13$

Relative canine dimorphism: Canine dimorphism/cranial dimorphism $=1.00$

'Asterisk indicates the larger measurement where males and females differ significantly $(\mathrm{P}<0.05)$. All measurements in mm. $\mathrm{N}=$ sample size, $\mathrm{OR}=$ observed range, $\overline{\mathrm{x}}=$ mean, $\mathrm{S}=$ standard deviation, and $\mathrm{V}=$ coefficient of variation for Adapis samples. For comparison, $\mathrm{V}_{\mathrm{n}}=$ average coefficient of variation for four nondimorphic species of Indriidae (Gingerich and Ryan, 1979), and $V_{d}=$ average coefficient of variation for three dimorphic species of Cebidae (Saimiri sciureus, Cebus apella, and Alouatta seniculus, Gingerich, unpublished).

in the transition from $A$. magnus to $A$. parisiensis. In $A$. parisiensis the maxillary canine is reduced to the point where it is within the range of nondimorphic primates, while the relative size of the mandibular canine is between that of dimorphic and nondimorphic primates.

Another important aspect of canine dimorphism that can be studied in Adapis is the relative variability of canine size within a species. Nondimorphic species have canine size distributed about a single mean value, whereas di- morphic species have canine size clustered about distinct male and female means. Intraspecific variability in relative canine size is directly related to the distance between the male and female means. In other words, the greater the separation between male and female means, the broader the distribution of individual canine sizes within any species. Or conversely, the broader the distribution, the greater the separation between male and female means and the greater the sexual dimorphism. 

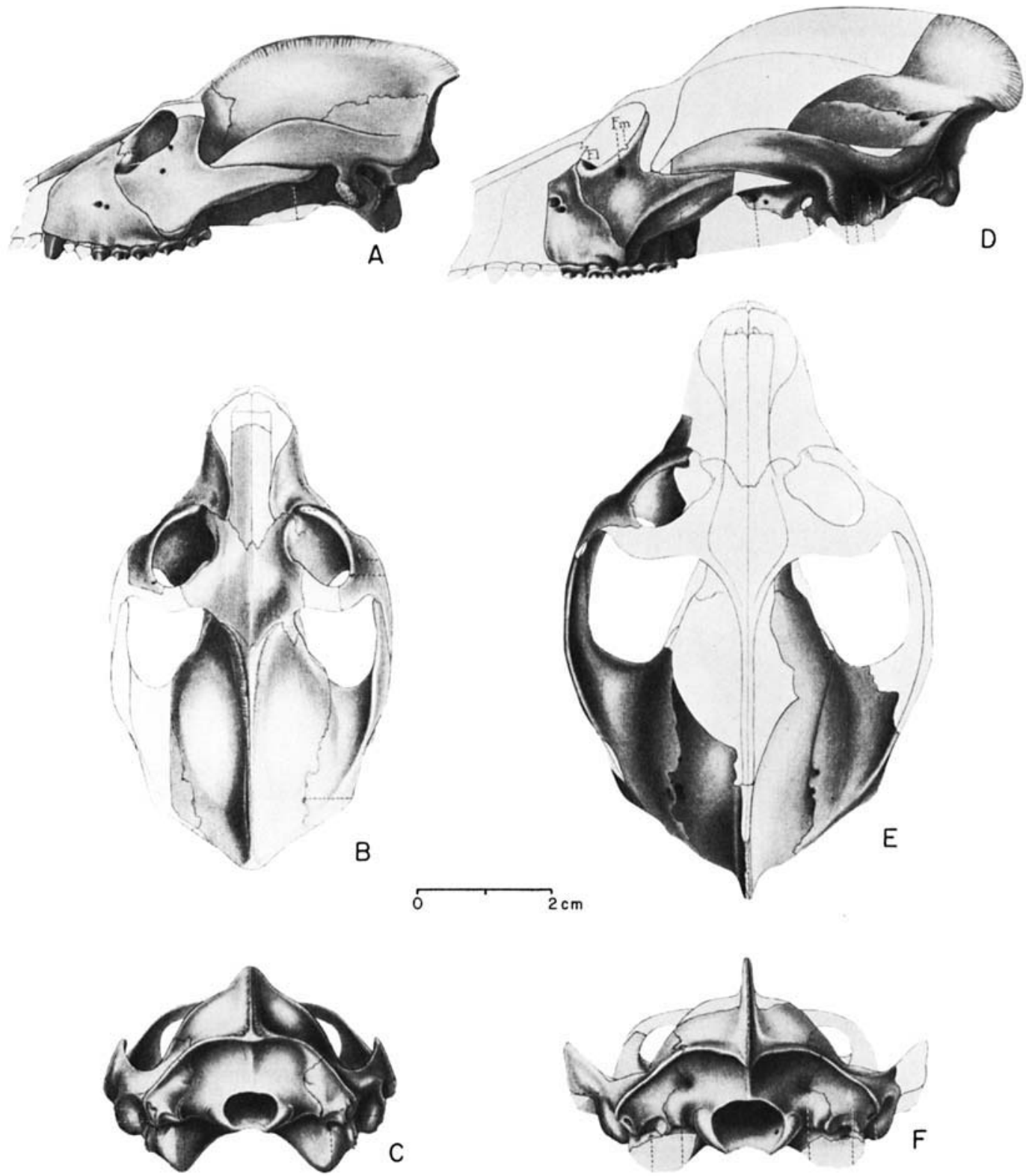

Fig. 4. Comparison of male and female crania of Adapis parisiensis. A-C, female (Montauban-4), in lateral, dorsal, and posterior view. D and E, male (Munich-1), in lateral, dorsal, and posterior view. Figures from Stehlin (1912).

The shape of the distribution of relative canine sizes can be quantified by use of the index of canine variability (ICV). This index is a form of corrected standard deviation or coefficient of variation, and it measures the shape of the distribution of relative canine sizes in the same way a coefficient of variation measures the shape of any normal distribution.
As expected, Table 3 shows that ICV values for living nondimorphic primates are lower (ICV = 8.3-14.0 in maxilla, 9.6-12.6 in mandible) than those of dimorphic primates (ICV = 15.4-33.6 in maxilla, 18.1-29.2 in mandible). In ICV value, Adapis magnus again falls within the range of sexually dimorphic primates. Adapis parisiensis is intermediate between di- 

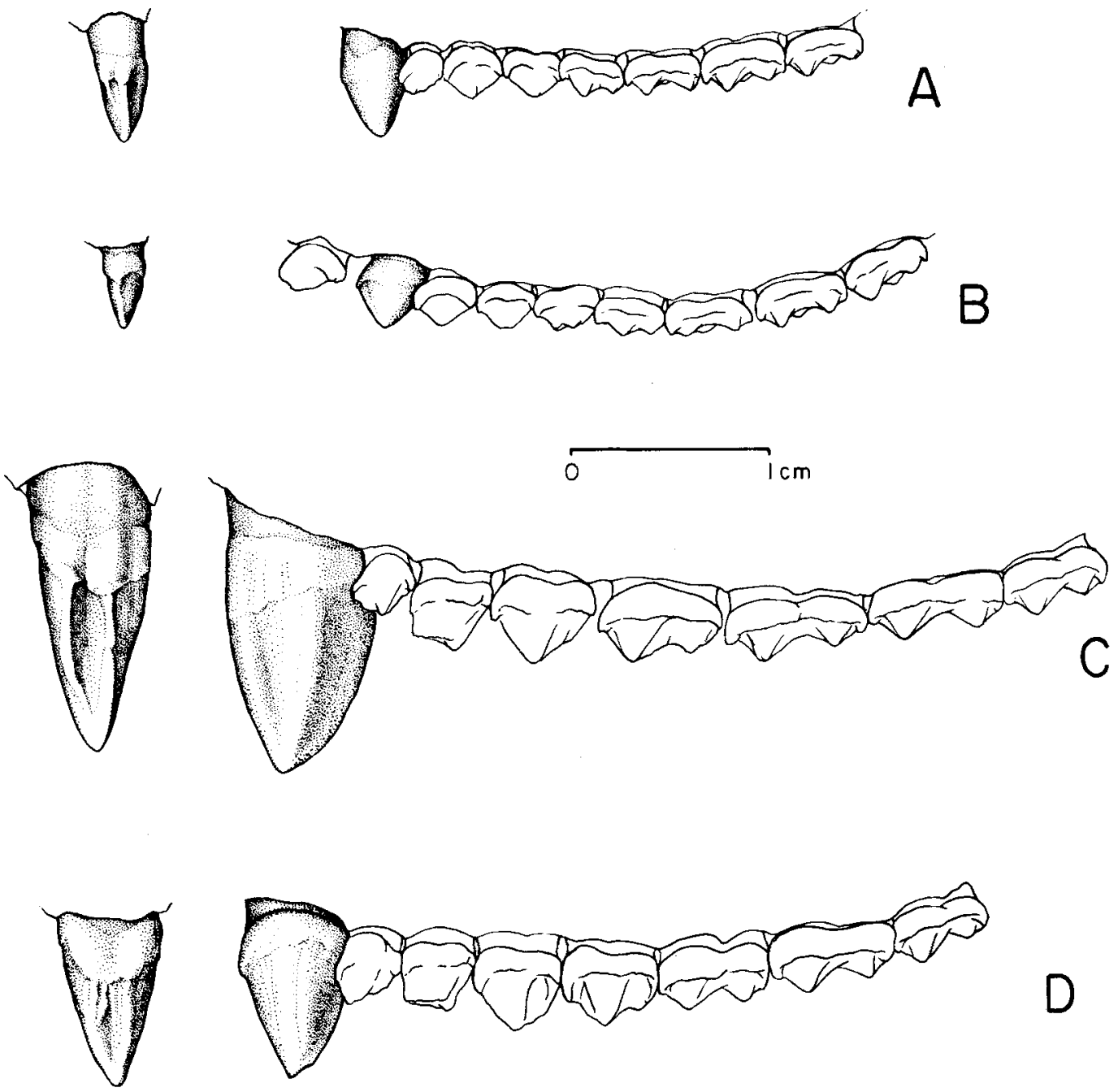

Fig. 5. Comparison of canine size in sexed specimens of Adapis magnus and Adapis parisiensis isex inferred from cranial size and morphology). All figures are of left upper canines (shaded) and maxillae in anterior and lateral view. $A$, male of A. parisiensis (Montpellier-5). B, male of $A$. parisiensis (Montauban-6). C, male of Adapis magnus (Montpellier-2). D, female of $A$. magnus (Montpellier-1). Note that the

morphic and nondimorphic primates in maxillary ICV, but well within the range of dimorphic primates in mandibular ICV.

Figure 6 shows the actual distribution of ICV values in $A$. parisiensis and $A$. magnus compared to those of two nondimorphic cebids (Callicebus and Aotus) and three dimorphic cebids (Saimiri, Cebus, and Alouatta). These histograms are standardized for comparison by development of the anterior groove is variable in the very reduced, premolariform canines of male $A$. parisiensis (A and B). Canine dimorphism is moderate in $A$. magnus but somewhat reduced in $A$. parisiensis (most females have reduced premolariform upper canines like those shown here in Montauban-6).

aligning mean Ln CMR values. ICV values for each histogram are shown in parentheses. In extant species, males are shaded and females are represented by open squares. Note that there is no separation of males and females in the nondimorphic species. Males clearly tend to have higher CMR values than females in dimorphic species, but there is sufficient overlap to make it difficult or impossible to sex inter- 
Callicebus moloch MAXILLA

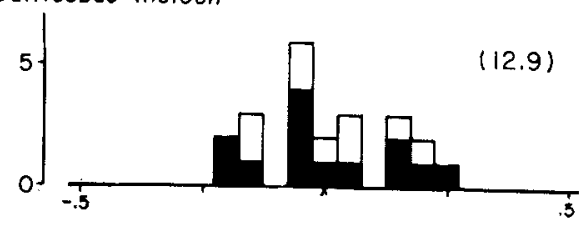

Aotus trivirgatus

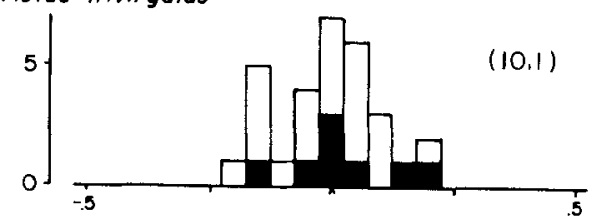

Saimiri sciureus

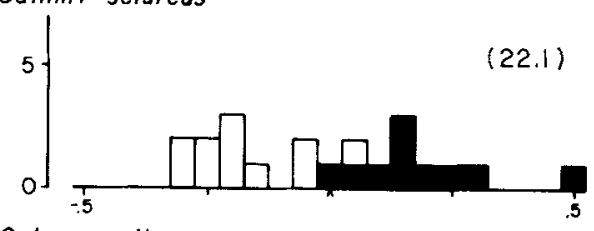

Cebus apella

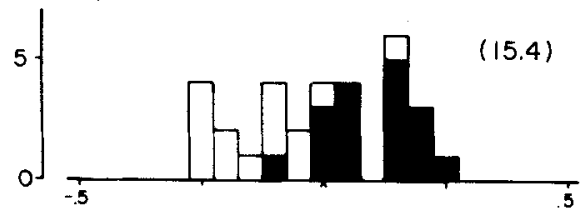

Alouatto seniculus

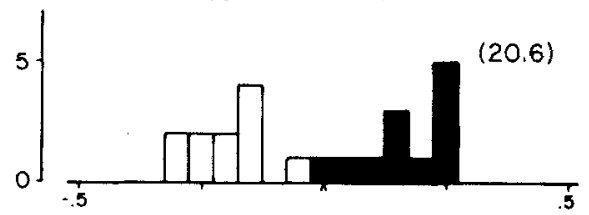

Adapis parisiensis

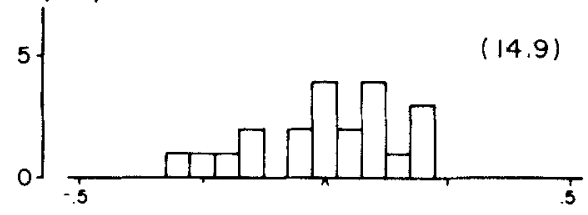

Adapis magnus

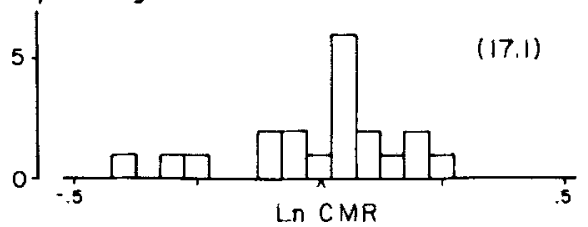

Fig. 6. Comparison of the distribution of $\mathrm{Ln} C \mathrm{CMR}$ in Eocene Adapis magnus and $A$. parisiensis with that in extant nondimorphic (Callicebus and Aotus) and dimorphic (Saimiri, Cebus, Alouatta) primates. All distributions plotted about a zero mean for ease of comparison. Solid squares
MANDIBLE
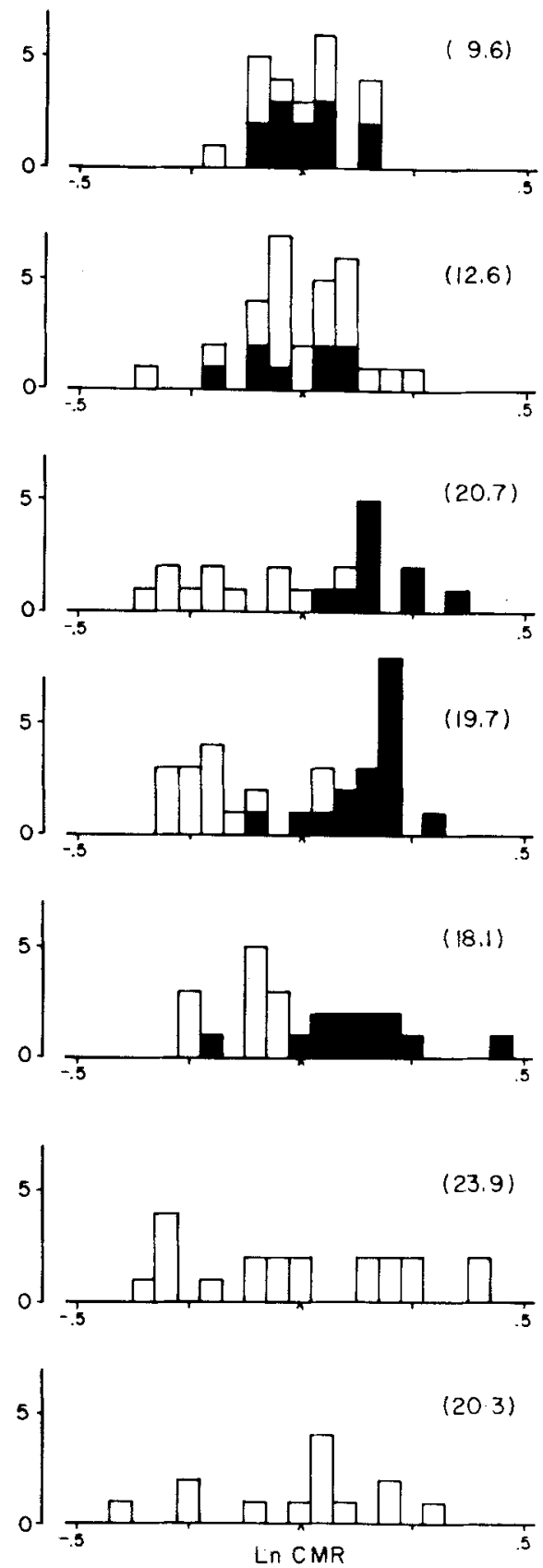

represent males; open squares represent females. Males and females overlap completely in CMR values in nondimorphic species, but tend to separate in dimorphic species. Note the broad distribution of CMR values in Adapis resembling that in dimorphic rather than nondimorphic living species. 
TABLE 3. Comparison of the distribution of canine size/molar size ratios (CMR) in Adapis magnus and Adapis parisiensis with those of representative sexually nondimorphic and dimorphic living primates

\begin{tabular}{|c|c|c|c|c|c|c|c|c|}
\hline \multirow[b]{2}{*}{ Genus and species } & \multicolumn{4}{|c|}{ Maxilla } & \multicolumn{4}{|c|}{ Mandible } \\
\hline & $\mathrm{N}$ & $\begin{array}{l}\text { Mean } \\
\text { CMR }\end{array}$ & ICS & ICV & $\mathrm{N}$ & $\begin{array}{l}\text { Mean } \\
\text { CMR }\end{array}$ & ICS & ICV \\
\hline \multicolumn{9}{|l|}{ Adapidae } \\
\hline Adapis magnus & 20 & 0.74 & -30.7 & 17.1 & 13 & 1.05 & 4.6 & 20.3 \\
\hline Adapis parisiensis & 21 & 0.57 & -56.4 & 14.9 & 20 & 0.83 & -18.8 & 23.9 \\
\hline \multicolumn{9}{|l|}{ Nondimorphic Prosimii } \\
\hline Hapalemur griseus & 16 & 0.51 & -68.4 & 11.9 & - & - & - & - \\
\hline Avahi laniger & 30 & 0.38 & -96.4 & 8.3 & - & - & - & - \\
\hline Propithecus verreauxi & 53 & 0.44 & -81.5 & 11.6 & - & - & - & - \\
\hline Propithecus diadema & 39 & 0.42 & -87.0 & 14.0 & - & - & - & - \\
\hline Indri indri & 51 & 0.47 & -75.3 & 9.9 & - & - & - & - \\
\hline \multicolumn{9}{|c|}{ Nondimorphic Anthropoidea } \\
\hline Callicebus moloch & 22 & 0.51 & -66.5 & 12.9 & 23 & 0.55 & -60.4 & 9.6 \\
\hline Aotus trivirgatus & 30 & 0.65 & -42.4 & 10.1 & 30 & 0.68 & -38.6 & 12.6 \\
\hline \multicolumn{9}{|l|}{ Dimorphic Anthropoidea } \\
\hline Saimiri sciureus & 21 & 0.90 & -10.5 & 22.1 & 21 & 0.95 & -5.3 & 20.7 \\
\hline Cebus apella & 31 & 1.51 & 41.5 & 15.4 & 31 & 1.45 & 37.3 & 19.7 \\
\hline Alouatto seniculus & 23 & 0.74 & -30.5 & 20.6 & 23 & 0.86 & -15.7 & 18.1 \\
\hline Alouatta caraya & 49 & 1.18 & 16.3 & 20.6 & 49 & 1.03 & 3.0 & 20.1 \\
\hline Pan troglodytes & 23 & 1.14 & 13.0 & 26.5 & 24 & 1.14 & 13.3 & 21.8 \\
\hline Gorilla gorilla & 40 & 1.07 & 6.5 & 33.6 & 38 & 0.93 & -7.5 & 29.2 \\
\hline
\end{tabular}

'Indices of relative canine size (ICS) and relative canine variability (ICV) are also given for comparison (see Equations 1-4 in text for derivation). $\mathrm{N}=$ sample size. Sources of data are given in the text. CMR, ICS, and ICV are not calculated for lower teeth of prosimians because the lower canine is either incorporated into a tooth comb or lost in the examples given.

mediate specimens based on the canine/molar ratio (although this is usually possible using absolute canine size in homogeneous extant samples).

The histograms in Figure 6 show graphically how the ICV values listed in Table 3 should be interpreted. Low ICV values are associated with narrow CMR distributions characteristic of nondimorphic species, whereas high ICV values are associated with broader CMR distributions of dimorphic species having distinct male and female means. Adapis magnus and Adapis parisiensis both have broad CMR distributions and, while most individual specimens cannot be sexed, it is clear that these species were as dimorphic in canine size as, for example, Cebus apella.

One obvious feature of the anterior surface of upper canine crowns in Adapis magnus is a deep groove (Fig. 5) similar to that seen on the canines of New and Old World anthropoids. The groove is more pronounced in large male specimens, but is also present on smaller female canines of $A$. magnus. In $A$. parisiensis, the groove is reduced or lost, and enough upper canines are preserved in sexed skulls to show that the presence or absence of this groove is not a reliable indication of sex (Fig. 5A, B).

\section{DISCUSSION}

Quantitative corroboration of Stehlin's (1912) hypothesis that Adapis was sexually di- morphic is important for three reasons: (1) it gives additional perspective on the social structure and paleobiology of Adapis; (2) it extends the documented record of sexual dimorphism in primates from Oligocene Anthropoidea to at least one Eocene prosimian genus; and (3) it suggests that some of Stehlin's subspecies and varieties are merely different sexes of Adapis magnus and Adapis parisiensis, respectively. The first two of these points require further discussion here.

\section{Sexual dimorphism and social structure}

Male and female roles in reproduction and parenting are different. Each contributes to succeeding generations in different ways. It follows that natural selection might affect different sexes in different ways. This is sometimes expressed in birds and mammals as a conspicuous sexual difference or dimorphism in plumage/pelage, body size, or size of the canine teeth. Sexual selection, different modes of response to predators, and divergent feeding specializations are all thought to be primary factors contributing to sexual dimorphism (Selander, 1966; Crook and Gartlan, 1966; Struhsaker, 1969; Crook, 1972; Trivers, 1972; Geist, 1974; Gautier-Hion, 1975; Downhower, 1976; Ralls, 1977; Emlen and Oring, 1977; Alexander et al., 1979; Martin, 1980).

In living primates (especially anthropoids), 
as in other mammals, there are conspicuous differences in pelage, body size, and canine size between males and females of some species. In recent years a number of people have investigated the relationship of sexual dimorphism in primate body size and canine size to various ecological and behavioral parameters. Among primates, dimorphism in body size can be explained by any or all of the three factors listed above: male intrasexual selection, a specialized male role in predator defense, and sexually divergent energy strategies (Coelho, 1974; Leutenegger and Kelly, 1977; Harvey et al., 1978; Martin, 1980). However, canine dimorphism exceeding that simply due to body size differences is most strongly associated with intrasexual selection (Leutenegger and Kelly, 1977; this does not, of course, preclude intrasexual selection as an important contributor to body size dimorphism when canine dimorphism is only equal to body size dimorphism).

Sampling, even in a fossil primate genus as well known as Adapis, imposes severe limits on how much one can reconstruct of the biology of extinct species. Nevertheless, the expression and significance of sexual dimorphism in modern primates is now sufficiently well studied to permit some generalization, and it is possible to use patterns of dimorphism in extant species to infer basic parameters of social structure in Adapis.

Cranial dimorphism. The ratio of male cranial length to female cranial length gives an approximation of the ratio of male body length to female body length. This ratio in Adapis ranges from 1.13 (in $A$. parisiensis) to 1.16 (in A. magnus), which is equivalent to a ratio of male/female body weights of about $1.13^{3}$ and $1.16^{3}$, or 1.44 and 1.56 , respectively. These values exceed those in all living monogamous primates. Male body length/female body length in monogamous primates ranges up to 1.08 (Alexander et al., 1979; the value for Aotus should be about 1.03), and male body weight/female body weight in monogamous primates ranges up to about 1.25 (Clutton-Brock et al., 1977). Thus, by comparison with living primate models, it is virtually certain that $A$ dapis had a polygynous breeding system.

Living arboreal primates with body weight dimorphisms approximating 1.50 have average socionomic sex ratios ranging from $1: 2$ to 1:4 (Clutton-Brock et al., 1977: Fig. 2), and this would be a reasonable range to expect in Adapis as well. The ratio of sexed male to female skulls listed in Table 1 is 4:4 for Adapis magnus and 7:5 for $A$. parisiensis, suggesting that the general sex ratio in both species was close to $1: 1$. This general ratio is effectively averaged over each entire species, including an indeterminate number of nonbreeding males, which explains the discrepancy between a general sex ratio of about 1:1 and a socionomic sex ratio estimated possibly to range from 1:2 to $1: 4$.

Canine dimorphism. Since it is impossible to sex most individual specimens, even when they preserve canines, it is difficult to make a reliable estimate of canine dimorphism in $\mathrm{Ada}$ pis. One way to do this is to compare the indices of canine size (ICS) and variability (ICV) for maxillary canines in Adapis with those for living primates given in Table 2. Adapis magnus is closest to Alouatta seniculus when both ICS and ICV values are considered, suggesting that Alouatta may be a suitable living model with canine dimorphism similar to that in $A$. magnus. Adapis parisiensis has relatively much smaller canines, but otherwise compares most closely with Cebus apella. Measuring canine size dimorphism in the same way as Leutenegger and Kelly (1977, but dividing male size by female size), Alouatta seniculus has a canine dimorphism of 1.22 and Cebus apella has a canine dimorphism of 1.16 .

Alternatively, canine dimorphism can be estimated by comparing male and female canines in the sexed skulls of Adapis magnus and $A$. parisiensis given in Table 1. Average male length/average female length gives an estimate of canine dimorphism of $1.19 \mathrm{in}$ A. magnus and 1.13 in A. parisiensis.

Relative canine dimorphism. Relative canine dimorphism (canine dimorphism divided by body size dimorphism) can be calculated following the method outlined by Leutenegger and Kelly (1977). Estimated this way, the relative canine dimorphism in $A$. magnus is 1.03 and in $A$. parisiensis it is 1.00 (Table 2).

Relative canine dimorphism can be calculated in a different way by comparing the observ. ed average size of male canines with the size of male canines predicted by enlarging an average female to the size of an average male (Harvey et al., 1978). In the absence of actual body weight measurements, it is necessary first to estimate the weight difference between males and females. If the average body weight of Adapis magnus is $8.4 \mathrm{~kg}$ (Gingerich and Martin, 1981) and the ratio of male to female body weights is 1.56 (see above), then an average female $A$. magnus should weigh about 6.56 $\mathrm{kg}$ and an average male should weigh about $10.24 \mathrm{~kg}$. Relative male tooth size (RMTS), calculated using the RMTS method of Harvey et al. (1978), is: 


$$
\begin{aligned}
\text { RMTS }= & \frac{\text { observed male tooth area }}{\text { expected male tooth area }} \\
& \times \frac{\text { expected female tooth area }}{\text { observed female tooth area }}
\end{aligned}
$$

The observed average female canine area in Adapis magnus is 33.54 (Table 1) and the expected female canine area, given a body weight of $6.56 \mathrm{~kg}$, is 31.89 (Harvey et al., 1978: Table 1). The observed average male canine area is 44.86 (Table 1) and the expected male canine area, given a body weight of $10.24 \mathrm{~kg}$, is 42.96 (Harvey et al., 1978: Table 1). Hence relative male canine size (RMTS, Equation 5) in $A$. magnus is 0.99. Assuming an average body weight in Adapis parisiensis of $2.0 \mathrm{~kg}$ (Fig. 1, and Gingerich and Martin, 1981; average female $=1.64 \mathrm{~kg}$, average male $=2.36 \mathrm{~kg}$ ) and taking canine size from Table 1 , relative male canine size in this species is $(12.23 / 16.09) \times$ $(12.62 / 9.39)=1.05$. The canines in $A$. magnus and $A$. parisiensis are dimorphic, but they are little or no more dimorphic than one would predict given the degree of body size dimorphism in Adapis. Considering these results in conjunction with those derived from Leutenegger and Kelly's method (above), there does not appear to be any substantial dimorphism in relative canine size in Adapis.

Monogamy or polygyny? Adapis is unusual among primates in combining moderate body size and canine size dimorphism with a virtual absence of relative canine dimorphism. Figure 7, adapted from Leutenegger and Kelly (1977), illustrates this graphically. In all primates, canine dimorphism is at least equal to body size dimorphism. Monogamous primates tend to have less body size dimorphism and less canine size dimorphism than polygynous primates, and there is a clear separation between the two breeding systems. From the information in Figure 7 it appears that Adapis magnus and $A$. parisiensis were almost certainly polygynous, however, their close proximity to the boundary separating polygynous from monogamous species argues in itself that the socionomic sex ratio was probably low in both species of Adapis.

The species closest to Adapis in body size dimorphism and canine size dimorphism, Cebus apella (Fig. 7), is a diurnal, arboreal, quadrupedal, omnivore intermediate between $A$. magnus and $A$. parisiensis in body size (Thorington, 1967; Fleagle and Mittermeier, 1980). Most of these characteristics apply to Adapis as well, and on present evidence Cebus apella would appear to be the best living model for Eocene Adapis. Cebus apella are polygynous and live in multimale troops of moderate size (Thorington, 1967; Fleagle, personal communication), and a similar social structure can be inferred for Adapis.

Any discussion of the selective basis for sexual dimorphism in Adapis is necessarily speculative. Polygyny can only evolve in situations where females are clumped in distribution, allowing some males to monopolize the reproductive effort of a disproportionate number of females. Clumping of females occurs because resources (food, water, sleeping sites, etc.) are unevenly distributed and cooperative female groups can compete more effectively for these (Wrangham, 1980), or because of the safety of numbers as a strategy for avoiding predation (Hamilton, 1971). In either case, males compete for access to females and male-male intraspecific competition or sexual selection normally favors larger, stronger males, leading to body size dimorphism and sometimes also to canine size dimorphism (Wilson, 1975; Alexander et al., 1979). It is also possible to argue that larger males with larger canines represent a specialization for the defense of kin against predators, or that males and females are different sizes to more efficiently divide scarce food items for which there is little interspecific competition. The relative contribution of each of these factors to sexual dimorphism is not yet well understood in living primates and, without a better understanding of paleoecology and faunal structure (including predators) in Adapis-bearing fossil sites, it is futile to speculate on the relative importance of sexual selection, predator defense, and ecological specialization in shaping sexual dimorphism in Adapis.

\section{Sexual dimorphism in primate history}

Among living primates, some degree of sexual dimorphism characterizes most higher simiiform or anthropoid primates, but prosimians rarely if ever exibit any body size or canine dimorphism. We do not yet know enough about the distribution of sexual dimorphism in fossil primates to draw firm conclusions about its phylogenetic history. At least moderate body size and/or canine dimorphism has been documented in three genera of Oligocene higher primates-Aegyptopithecus, Propliopithecus, and Apidium (Fleagle et al., 1980). These genera are the oldest anthropoids known from specimens adequate to indicate the presence or absence of dimorphism but there are not as yet enough canines or associated crania to permit quantitative comparison with the results pre- 


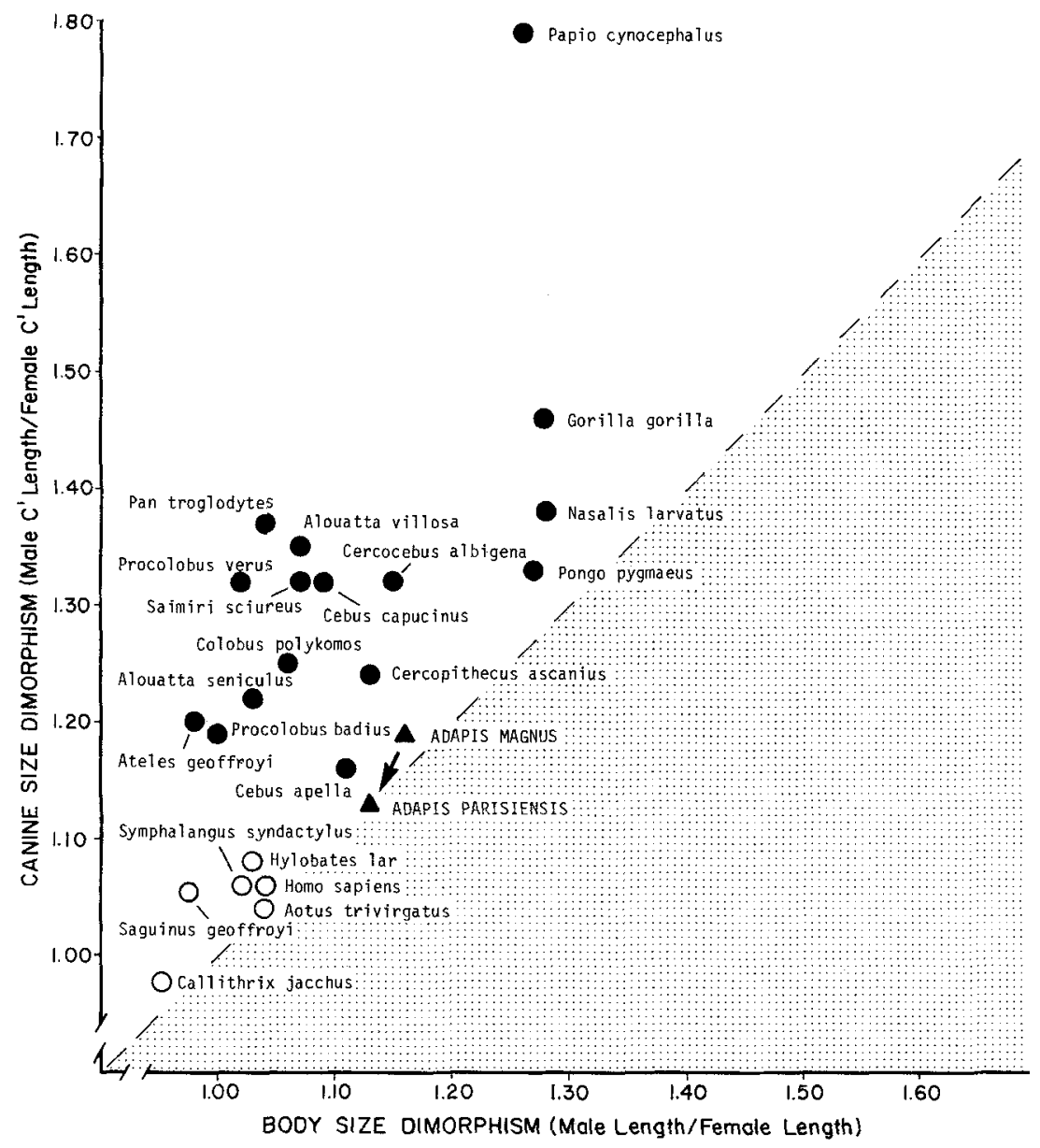

Fig. 7. Relationship of canine size dimorphism and body size dimorphism in primates. Graph is inverted and redrawn from Leutenegger and Kelly (1977), with the addition of fossil species Adapis magnus and Adapis parisiensis (triangles, Table 2); extant species Aotus trivirgatus, Saimiri sciureus, Cebus apella, and Alouatta seniculus (based on cranial measurements gathered for this study); and corrected values for Symphalangus syndactylus (Schultz, 1973). Positions of extant monogamous species are shown by open circles, posi-

sented here. Aegyptopithecus, Propliopithecus, and Apidium are phylogenetically close to the origin of higher primates, which suggests that dimorphism is almost certainly the primitive ancestral condition among Anthropoidea (or Simiiformes). If this is so, it implies that dimorphism and associated polygynous breeding systems have been replaced by nondimorphic monogamous breeding systems a minimum of two times in the course of higher primate evolution, at least once (if not three times) in the evolution of the smaller ceboids (Callithrix and its relatives, Callicebus, tions of extant polygynous species are shown by closed circles. Dashed line represents canine size dimorphism equal to body size dimorphism; no species fall below this line (shaded area). Relative canine dimorphism, as defined by Leutenegger and Kelly, is equal to the slope of a line connecting a given point with the origin. The combined measure of dimorphism (CMD, Equation 6) used here is equal to the distance of a given point from the origin.

and Aotus) and at least once (if not twice) in the evolution of apes and humans (Hylobates-Symphalangus, and Homo). Adapis is often suggested as a possible ancestor, in some broad sense, of extant Lemuroidea and Lorisoidea. Evidence discussed here indicates that this hypothesis would require the evolutionary loss of sexual dimorphism and a polygynous breeding system in favor of monomorphism and monogamy at least one additional time in primate history, since extant lemuroids and lorisoids are typically nondimorphic and either monogamous or promiscuous. 
If the oldest-known higher primates are sexually dimorphic, it is reasonable to expect that the group they evolved from was dimorphic as well. I have outlined the dental, cranial, and postcranial evidence favoring an origin of higher primates from Adapidae (Gingerich, $1981 \mathrm{a}, \mathrm{b})$, and the presence of sexual dimorphism in Adapidae is consistent with this hypothesis. To my knowledge there is no evidence that Eocene Omomyidae were sexually dimorphic. While the absence of sexual dimorphism by itself certainly does not eliminate Omomyidae from consideration as the group ancestral to higher primates (it is possible that dimorphism and polygyny originated more than once in primates; they certainly evolved independently in other orders of mammals; Gingerich, 1981c), sexual dimorphism is one additional characteristic favoring the origin of higher primates from Eocene Adapidae.

\section{Reduction in body size and canine dimorphism}

One remaining question concerns the reduction in body size and canine dimorphism seen in the transition from Adapis magnus to Adapis parisiensis. The Eocene was an epoch of warm equable climates in the middle and high latitudes encompassing Europe and North America, and primate diversity at those latitudes was at its highest during the Eocene. However, a profound climatic deterioration took place during an interval of approximately 2 million years in the middle and late Lattorfian, i.e., at the end of the Eocene or in the earliest Oligocene. This climatic deterioration involved a major decline in mean annual temperature (of about $10-11^{\circ} \mathrm{C}$ ) and a marked increase in seasonality (from a range of $5^{\circ} \mathrm{C}$ to an annual range of about $21^{\circ} \mathrm{C}$; Wolfe, 1978). Ultimately, one result of this deterioration was marked faunal turnover, the Grande Coupure of Stehlin (1909), which included replacement of the entire European (and North American) Eocene primate fauna by orders better adapted to temperate climates. As Figure 1 shows, the diversity of Eocene Adapidae decreased during the late Eocene, presumably in response to climatic change, and Adapis decreased markedly in body size before becoming extinct in Europe. Gestation period, generation length, and lifespan (Sacher, 1959) are all related to body size, and it is possible to view decreasing body size in Adapis as an adaptation for more rapid reproduction in response to density-independent selection associated with environmental instability (cf. Gould, 1977: p. 324).
Increasing climatic seasonality during the Eocene-Oligocene transition would also have had a profound effect on vegetative flowering and fruiting patterns, and it is possible that increased seasonality of food availability was responsible for reduction of the canine teeth in Adapis and their incorporation into a functional unit with the incisors. Primates in seasonal environments today subsist during part of the year on gums and resins exuded from trees (Martin, 1972; Kinzey et al., 1975; CoimbraFilho and Mittermeier, 1978; Bearder and Martin, 1980). The reduced canines in Adapis parisiensis (Fig. 8) resemble those in "short-tusked" callitrichids (Coimbra-Filho and Mittermeier, 1978), and may represent another "short-tusked" adaptation for seasonal subsistence on gums and resins. Negligible relative canine dimorphism in Adapis magnus suggests that the canines could be modified in form and function in Adapis parisiensis without affecting body size dimorphism or social structure significantly.

\section{ACKNOWLEDGMENTS}

I thank Drs. P. Andrews and T. Molleson, British Museum (Natural History) [BMNH], London; K.A. Joysey and A. Friday, University Museum of Zoology, Cambridge; L. van de Poel, Geologisch Instituut der Katholieke Universiteit, Leuven; H.W. Matthes, Geiseltalmuseum, Halle; R. Dehm and N. Schmidt-Kittler, Institut für Paläontologie und Historisches Geologie, Munich; J. Hürzeler and B. Engesser, Naturhistorishes Museum, Basel; D.E. Russell, Muséum National d'Histoire Naturelle [MNHN], Paris; J. Lafond, Muséum d'Histoire Naturelle, Bordeaux; P. Mein, Université Claude Bernard, Lyon; A. Cavaillé, Musée de Montauban, Montauban; J.A. Remy, Musée de Nimes, Nimes; L. Thaler and J. Sudre, Université des Sciences et Techniques du Languedoc, Montpellier; F.A. Jenkins, Museum of Comparative Zoology, Cambridge, Mass.; and D. Baird, Princeton University, Princeton, for access to specimens of Adapis magnus and $A$. parisiensis included in this study. Dr. R.D. Martin permitted me to study the Cambridge skull of Adapis in London (see following report), and Dr. F.S. Szalay permitted me to study Montauban specimens of Adapis in New York. Drs. P. Napier, British Museum (Natural History), London; F.K. Jouffroy, Muséum National d'Histoire Naturelle, Paris; L.B. Holthuis, Rijksmuseum van Natuurlijke Histoire, Leiden; P. Helwig, 


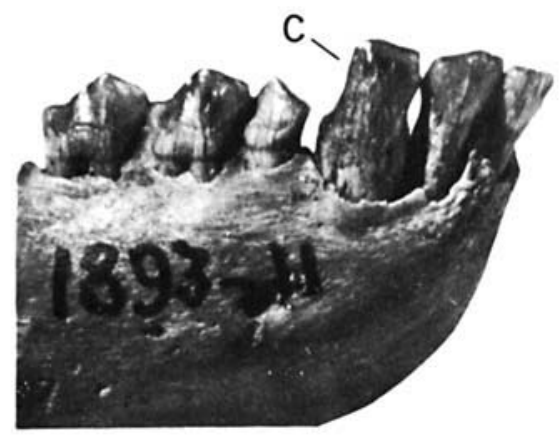

A
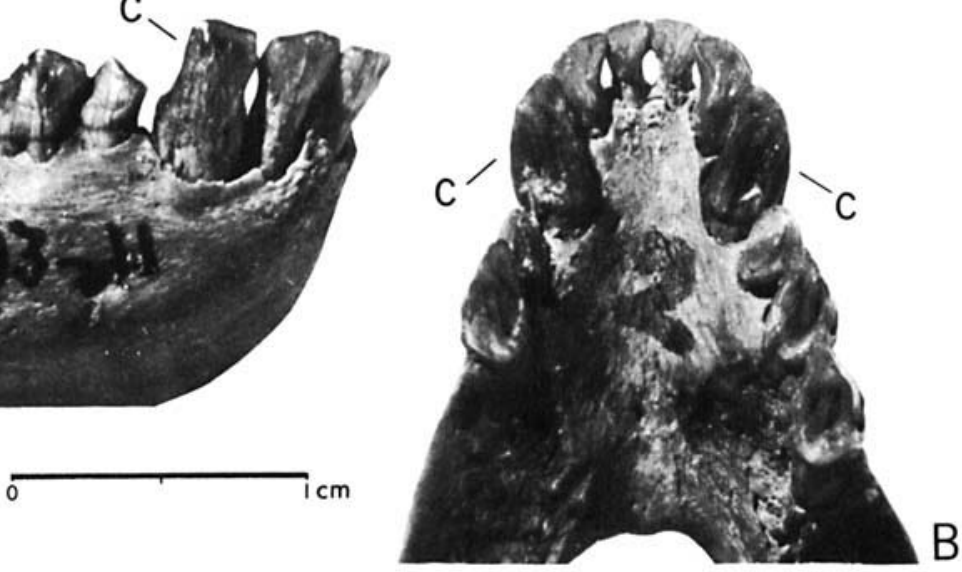

Fig. 8. Anterior lower dentition of Adapis parisiensis in lateral (A) and occlusal view (B). Note "short-tusked" incisiform canines (C) forming a functional unit with the incisors. Specimen is MNHN (Paris)-10956 from Quercy, $3 \times$ natural size.

Cleveland Museum of Natural History, Cleveland; and P. Freeman, Field Museum of Natural History, Chicago, permitted access to osteological collections of most of the recent primates listed in Table 2. Dr. M.J. Schoeninger helped measure the four ceboid species in Chicago. Drs. M. Zingeser and W. Kinzey generously made available their measurements of Alouatta caraya and Callicebus moloch. Karen Payne drew the specimens in Figure 5. I thank Dr. J.G. Fleagle for presenting a preliminary version of this paper (Gingerich, 1979b) at the 1979 annual meeting of the American Association of Physical Anthropologists, San Francisco. Dr. J.G. Fleagle, Dr. L.B. Radinsky, and Mr. D.W. Krause read and improved the manuscript. This study was initiated in 1975 during tenure of a NATO postdoctoral fellowship in the Laboratoire de Paléontologie, Université de Montpellier, and completed with support from National Science Foundation grant BNS 80-16742.

\section{LITERATURE CITED}

Alexander, RD, Hoogland, JL, Howard, RD, Noonan, KM, and Sherman, PW (1979) Sexual dimorphisms and breeding systems in pinnipeds, ungulates, primates, and humans. In NA Chagnon and W Irons (eds): Evolutionary Biology and Human Social Behavior: An Anthropological Perspective. North Scituate, Mass.; Duxbury Press, pp. $402-435$

Bearder, SK, and Martin, RD (1980) Acacia gum and its use by bushbabies, Galago senegalensis (Primates: Lorisidae). Int. J. Primatol. 1:103-128.

Clutton-Brock, TH, Harvey, PH, and Rudder, B (1977) Sex- ual dimorphism, socionomic sex ratio, and body weight in primates. Nature 269:797-800.

Coelho, AM (1974) Socio-bioenergetics and sexual dimorphism in primates. Primates 15:263-269.

Coimbra-Filho, AF, and Mittermeier, RA (1978) Tree-gouging, exudate-eating, and the "short-tusked" condition in Callithrix and Cebuella. In DG Kleiman (ed): The Biology and Conservation of the Callitrichidae. Washington, D.C.: Smithsonian Institution Press, pp. 105-115.

Crook. JH (1972) Sexual selection, dimorphism, and social organization in the primates. In B. Campbell (ed): Sexual Selection and the Descent of Man. London: Heinemann, pp. $231-281$.

Crook, JH, and Gartlan, JS (1966) Evolution of primate societies. Nature 210:1200-1203.

Depéret, C. (1917) Monographie de la faune de mammifères fossils du ludien inférieur d'Euzet-les-bains (Gard). Ann. Univ. Lyon 40:1-290.

Downhower, JF (1976) Darwin's finches and the evolution of sexual dimorphism in body size. Nature 263:558-563.

Emlen, ST, and Oring, LW (1977) Ecology, sexual selection, and the evolution of mating systems. Science 197:215-223.

Fleagle, JG (1978) Size distributions of living and fossil primate faunas. Paleobiology 4:67-76.

Fleagle, JG, Kay, RF, and Simons, EL (1980) Sexual dimorphism in early anthropoids. Nature 287:328-330.

Fleagle, JG, and Mittermeier, RA (1980) Locomotor behavior, body size, and comparative ecology of seven Surinam monkeys. Am. J. Phys. Anthropol. 52:301-314.

Gautier-Hion, A (1975) Dimorphism sexuel et organisation sociale chez les cercopithécinés forestiers africains. Mammalia 39:365-374.

Geist, V (1974) On the relationship of social evolution and ecology in ungulates. Am. Zool. 14:205-220.

Gingerich, PD (1974) Size variability of the teeth in living mammals and the diagnosis of closely related sympatric fossil species. J. Paleontol. 48:895-903.

Gingerich, PD (1975) Dentition of Adapis parisiensis and the evolution of lemuriform primates. In I Tattersall and RW Sussman (eds): Lemur Biology. New York: Plenum, pp. $65-80$. 
Gingerich, PD (1977) New species of Eocene primates and the phylogeny of European Adapidae. Folia Primatol. 28: 60-80.

Gingerich, PD (1979a) Phylogeny of middle Eocene Adapidae (Mammalia, Primates) in North America: Smilodectes and Notharctus. J. Paleontol. 53:153-163.

Gingerich, PD (1979b) Sexual dimorphism in Eocene Adapidae: Implications for primate phylogeny and evolution [Abstraet]. Am. J. Phys. Anthropol. 50:442.

Gingerich PD (1980) Dental and cranial adaptations in Eocene Adapidae. Z. Morphol. Anthropol. 71:135-142.

Gingerich, PD (1981a) Eocene Adapidae, paleobiogeography, and the origin of South American Platyrrhini. In RL Ciochon and AB Chiarelli (eds): Evolutionary Biology of the New World Monkeys and Continental Drift. New York: Plenum, pp. 123-138.

Gingerich, PD (1981b) Early Cenozoic Omomyidae and the evolutionary history of tarsiiform primates. J. Human Evol. 10: in press.

Gingerich, PD (1981c) Variation, sexual dimorphism, and social structure in the early Eocene horse Hyracotherium tapirinum. Paleobiol. 7 : in press.

Gingerich, PD, and Martin, RD (1981) Cranial morphology and adaptations in Eocene Adapidae. II. The Cambridge skull of Adapis parisiensis. Am. J. Phys. Anthropol. 56:235-257.

Gingerich, PD, and Ryan, AS (1979) Dental and cranial variation in living Indriidae. Primates 20:141-159.

Gingerich, PD, and Schoeninger, MJ (1979) Patterns of tooth size variability in the dentition of primates. Am.J. Phys. Anthropol. 51:457-466.

Gingerich, PD, Smith, BH, and Rosenberg, K (1981) Allometric scaling in the dentition of primates and prediction of body weight from tooth size in fossils. Am. J. Phys. Anthropol., to be submitted.

Gould, SJ (1977) Ontogeny and Phylogeny. Cambridge, Mass.: Belknap Press, Harvard University.

Gregory, WK (1920) On the structure and relations of Noth arctus, an American Eocene primate. Mem. Am. Mus. Nat. Hist. 3:49-243.

Hamilton, WD (1971) Geometry for the selfish herd. J. Theor. Biol, 31:295-311.

Harvey, PH, Kavanagy, M, and Clutton-Brock, TH $\{1978\}$ Sexual dimorphism in primate teeth. J. Zool. (Lond.) 186: 475-485.

Kay, RF (1975) The functional adaptations of primate molar teeth. Am. J. Phys. Anthropol. 43:195-216.

Kay, RF, and Hylander, WL (1978) The dental structure of mammalian folivores with special reference to primates and phalangeroids (Marsupialia). In GG Montgomery (ed): The Ecology of Arboreal Folivores. Washington D.C.: Smithsonian Institution Press. pp. 173-191.

Kinzey, WG (1972) Canine teeth of the monkey Callicebus moloch: Lack of sexual dimorphism. Primates 13: 365-369.

Kinzey, WG, Rosenberger, AL, and Ramiriz, M (1975) Ver tical clinging and leaping in a neotropical anthropoid. $\mathrm{Na}$ ture 255:327-328.
Leutenegger, W, and Kelly, JT (1977) Relationship of sexual dimorphism in canine size and body size to social, behavioral, and ecological correlates in anthropoid primates. Primates 18:117-136.

Martin, RD (1972) Adaptive radiation and behavior of the Malagasy lemurs. Philos. Trans, R. Soc. Lond. (Biol.) 264: $295-352$.

Martin, RD (1980) Sexual dimorphism and the evolution of higher primates. Nature 287:273-275.

Pilbeam, DR (1969) Tertiary Pongidae of East Africa: Evolutionary relationships and taxonomy. Bull. Peabody Mus. Nat. Hist., Yale Univ. 31:1-185.

Pilbeam, DR, and Zwell, M (1972) The single species hypothesis, sexual dimorphism, and variability in early homin. ids. Yrbk. Phys. Anthropol. 16:69-79.

Ralls, K (1977) Sexual dimorphism in mammals: Avian models and unanswered questions. Am. Nat. 111: $917-938$.

Sacher, GA (1959) Relation of lifespan to brain weight and body weight in mammals. CIBA Foundation Colloquia on Aging 5:115-141.

Schmidt-Kittler, N (1971) Eine unteroligozäne Primatenfau na von Ehrenstein bei Ulm. Mitt. Bayer. Staatssamml. Paläontol. Hist. Geol. 11:171-204.

Schultz, AH (1973) The skeleton of the Hylobatidae and other observations on their morphology. In DM Rumbaugh (ed): Gibbon and Siamang. Basel: Karger, 2:1-54.

Selander, RK (1966) Sexual dimorphism and differential niche utilization in birds. Condor 68:113-151.

Stehlin, HG (1909) Remarques sur les faumules de mammifères des couches éocènes et oligocenes du Bassin de Paris. Bull. Soc.Géol. France (Sér. 4) 9:488-520.

Stehlin, HG (1912) Die Säugetiere des schweizerischen Eocaens-Adapis. Abh. Schweiz. Paläont. Ges. 38:11151298.

Struhsaker, TT (1969) Correlates of ecology and social organization among African cercopithecines. Folia Primatol. 11:80-118.

Szalay, FS (1976) Systematics of the Omomyidae (Tarsiiformes, Primates): Taxonomy, phylogeny, and adaptations. Bull. Am. Mus. Nat. Hist. 156:157-405.

Thorington, RW (1967) Feeding and activity of Cebus and Saimiri in a Colombian forest. In $D$ Stark, $R$ Schneider, and HJ Kuhn (eds): Neue Ergebnisse der Primatologie. Stuttgart: Gustav Fischer, pp. 180-184.

Trivers, RL (1972) Parental investment and sexual selection. In B Campbell (ed): Sexual Selection and the Descent of Man. London: Heinemann, pp. 136-179.

Wilson, EO (1975) Sociobiology: The New Synthesis. Cambridge, Mass.: Belknap Press, Harvard University.

Wolfe, JA (1978) A paleobotanical interpretation of 'Tertiary climates in the Northern Hemisphere. Am. Scientist 66: 694-703.

Wrangham, RW (1980) An ecological model of femalebonded primate groups. Behaviour 75:262-300.

Zingeser, RM (1967) Odontometric characteristics of the howler monkey (Alouatta caraya). J. Dent. Res. (Suppl.) 46:975-978. 